\title{
As dúas mais do Sandro
}

\author{
Xavier Frías Conde
}

O facto de ter dúas mais e ningún pai non era un problema para o Sandro. Si, el era un deses casos de fillo de dúas mais, porque ambas as súas mais estaban casadas entre elas. Pouco lle importaba a el que unha fose a mai biolóxica e a outra non, mais parecía que ao resto da vila onde vivía desde había algúns meses si lle interesaba moito aquel facto.

O Sandro maldicía o día en que foran morar para aquela vila do interior do país, lonxe da capital, por causa do traballo dunha das súas mais. Toda a súa vida decorrera felizmente na capital, aquel universo de persoas, luces e historias onde ninguén lle preguntaba por que é que tiña dúas mais, se callar, porque nin o sabían, ou talvez porque houbese cousas máis interesantes en que pensar. Sabía que nos lugares pequenos tiñan outra maneira de ver as cousas, mais non até o punto de o desprezaren así por ter a familia que tiña. Tampouco non lle servía de consolación aquela frase, para el baldeira, que un antigo mestre lle dixera na escola: "Un non escolle a familia, mais si os amigos». Porén, el estaba feliz coa súa familia, non quería calquera outra.

Por iso, desde había cerca de seis meses, xusto desde que na escola souberon que el tiña dúas mais e ningún pai, el era o ser máis estraño do mundo para aquela xente, que non o querían ter en derredor por medo a se contaxiaren de algo, non se sabía moito ben de que, mais si de algo. O Sandro non quería falar diso na casa. Ben sabía el que as súas mais xa tiñan problemas demais, que tamén elas eran vistas como seres estraños, onde unha delas tiña que ser o pai, porque era inimaxinábel que naquela familia non houbese un pai, tiña que habelo á forza. Das dúas mais, a Aurora tiña os cabelos curtos, por tanto no imaxinario da vila ela era o pai, aínda que fose un pai castrado. Alén diso, coincidía con que ela non era a mai biolóxica, mais era a Lurdes.

As cousas para o Sandro peoraron cando a Carmiña quixo gañar puntos entre a rapazada. Ela era precisamente unha rapariga de aspecto masculino, que até gostaba de lidar cos rapaces da vila cos puños. Vira no Sandro unha vítima ideal para ela poder gañar prestixio naquela especie de banda de rapaces que pretendía liderar. Sabía que a crueldade e a violencia lle farían gañar puntos entre aqueles rapaces adoradores da violencia gravada en telemóbil. Ela soa bateu no rapaz chea de furia nun recanto da vila, xorda aos berros del pedindo piedade, mentres o resto rían ás gargalladas e gravaban a cena nos telemóbiles. Todo ía acompañado de berros de "marica de merda" ou "familia de maricas", como se a Carmiña quixese que o Sandro pagase nas súas carnes que existisen familias como a súa.

Cando o Sandro chegou á casa, xa non puido esconder por máis tempo a súa situación. A Aurora e a Lurdes sandaron as feridas na casa, non quixeron que aquel incidente aínda tivese máis eco na vila. Porén, no silencio de ambas as mulleres resoaba a idea de marcharen de alí e regresaren á cidade, aínda que alí ficase o traballo. Temían inclusive que con aquela agresión se tivese levantado a veda da caza e que a homofobía puidese ser expresada por toda a vila.

E así foi, con efecto. Desde aquel día, as persoas xa nin disimulaban chamar "blasfemos" a todos os membros da familia. O Sandro ficou aínda máis illado, se iso xa era posíbel. Inclusive algúns dos mestres na escola, até aquela altura máis tépedos, pasaron a axir contra o rapaz. 
A discriminación era evidente, o ambiente irrespirábel. Se aquilo tivese acontecido trescentos anos atrás, toda a familia estaría xa arder no picouto nas mans da Inquisición, mais a Inquisición, no fundo, continuaba a existir, doutra maneira, adaptada ao século XXI, mais ben aferrada ás mentes daqueles vilegos.

- Sandro - dixeron ao rapaz as súas maisde aquí a unha semana xa marchamos desta vila. Isto é un inferno e non queremos que sexas quen máis o sufras, fillo.

O rapaz mal mexeu a cabeza en sinal de asentimento. Tamén el concordaba con aquela decisión.

Porén, varios días antes da marcha prevista, a Carmiña entrou na sala de aula con sinais de ter recibido unha losqueada brutal. A súa meixela aínda deixaba entrever a marca dos dedos da man que executara o castigo. A primeira reacción dos compañeiros da turma foi ollaren para o Sandro.

-Non foi el —explicou a Carmiña, o cal resultaba críbel, porque ninguén achaba que o Sandro tivese nin o valor nin a forza de bater na Carmiña.

Porén, a rapaza non dixo o que acontecera, gardouno para ela. Ademais, a partir dese momento, a presión sobre o Sandro e a súa familia reduciu considerabelmente. Pasaron de ser observados hostilmente a simplemente ser ignorados. Era algo mellor, mais mesmo así non era agradábel vivir nun lugar como aquel.

A noite antes da partida, petaron na porta da casa da familia do Sandro. Levaron unha sorpresa enorme cando comprobaron que quen acudía alí era a Carmiña e unha muller anciá que se presentou como a súa avoa materna.

- Perdoen esta visita intempestiva - dixo a muller-, mais sei que mañá marchan deste pobo. E eu laméntoo moito. Querería pedirlles escusas no meu nome e no dos meus veciños polo mal causado.

Mentres a avoa falaba, a Carmiña non deixaba de ollar para o chan, como envergoñada. A Lurdes pediu á muller que pasase. Ofrecéronlle un copo de viño branco. Notábase que a muller quería falar, precisaba falar, desabafar por toda a tensión xerada na vila e da que ela tamén se sentía responsábel, talvez por omisión.

—Eu admíroas — recoñeceu finalmente a anciá-. As señoras mostraron o seu amor sen escondelo. Eu non tiven tanta coraxe.

A Lurdes e a Aurora espetaron os ollos nela, abraiadas. Quedaron á espera de a muller lles contar máis. A neta continuaba a ollar para o chan, mais escoitaba as palabras da avoa.

-Antes da guerra, eu casei cun home. El morreu durante a guerra, mais eu xa estaba encinta. Tiven unha filla, a mai desta miña neta, a Carola. Porén, eu estaba moi soa e precisaba axuda. A miña cuñada, a Elvira, veu vivir comigo. Ela tamén estaba soa e perdera todo na vida. A cuestión é que temos vivido xuntas desde hai sesenta anos. Ela agora está na casa. Ten alzhéimer, non coñece ninguén. Só sorrí cando eu lle acariño o rostro, só entón...

A avoa tivo que facer un esforzo para non romper a chorar.

-A Elvira é o amor da miña vida. Naqueles tempos, que dúas mulleres vivisen xuntas e criasen os fillos de unha delas non era estraño se unha era viúva; porén, houbo moitos máis casos como o noso, de amores de mulleres ás escondidas, tamén nesta vila. Hipócritas. Nós nunca declaramos o noso amor, gardámolo para nosoutras, por medo, aínda hoxe. E criamos xuntas a miña filla Carola e cando ela morreu, tamén esta miña neta. Por iso, cando souben o que a Carmiña fixera con seu fillo, non puiden evitar darlle unha labazada e despois contarlle a nosa historia. Estúpida!

A Carmiña continuaba a ollar para o chan. Quería pasar desapercibida; se callar, até unha bágoa se debruzaba polo canto dun ollo. A avoa finalmente non puido aturar as bágoas e chorou por toda unha vida na casa daquelas dúas estrañas perante as que se sentía obrigada a dar explicacións que ninguén lle pedira.

Ao amañecer do outro día, o auto familiar da Lurdes, a Aurora e o Sandro abandonaba aquela vila que aínda non acordara, moi devagar, como se non quixese facer barullo ningún e que ninguén notase aquela partida longamente anunciada. 